\title{
Ovarian Monodermal and Highly Specialized Teratoma
}

National Cancer Institute

\section{Source}

National Cancer Institute. Ovarian Monodermal and Highly Specialized Teratoma. NCI

Thesaurus. Code C8113.

A teratoma of the ovary composed exclusively or predominantly of a single type of tissue derived from the ectoderm or endoderm. A representative example is struma ovarii which is a teratoma composed exclusively or predominantly of thyroid tissue. 